\title{
BIOTIC AND ABIOTIC EVENTS IN A SHALLOW CARBONATE PLATFORM (UPPER CRETACEOUS, SOUTH PYRENEAN MARGIN)
}

\author{
Caus E. ${ }^{1}$, Albrich S. ${ }^{1}$, Berástegui X. ${ }^{2}$, Bernaus J. M. ${ }^{3}$, Boix C. ${ }^{1}$, and \\ Villalonga $\mathbf{R}^{1}$
}

${ }^{1}$ Universitat Autònoma de Barcelona, Department of Geology (Paleontology), 08193-Bellaterra, Spain.esmeralda.caus@uab.es,sergi.albrich@campus.uab.es, carme.boix@campus.uab.es, raquel.villalonga@campus.uab.es

${ }^{2}$ Institut Geològic de Catalunya, Balmes, Barcelona-08006, Spain.xberastegui@igc.cat

${ }^{3}$ Oolithica Geosciences LTd., Lower Ground Floor 53/57 Rodney Rd. Cheltenham GL50 1HX. United Kingdom(present address: Statoil ASA, GEX N-AFR D5-FH, N-4035, Stavanger, Norway. JMBE@statoil.com

\begin{abstract}
A detailed sedimentological and paleontological study of the Late Santonian-Late Campanian carbonate platform deposits of the Serres Marginals area (South margin of the Pyrenean Basin) has been performed. Three depositional shallow carbonate sequences have been distinguished (C1, C2 and C3). Within the shallow platform sequences moderate energy subtidal to intertidal, high energy sand-shoal, protected lagoon and restricted lagoon to lacustrine facies have been identified.
\end{abstract}

Key words: Carbonate platform, larger foraminifera, Upper Cretaceous, South Pyrenean margin.

\section{Пврі́̊пчи}

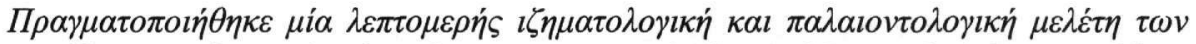

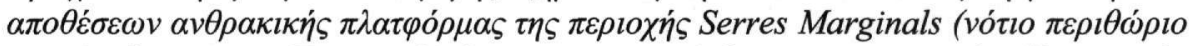

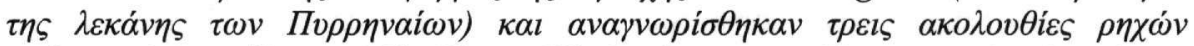

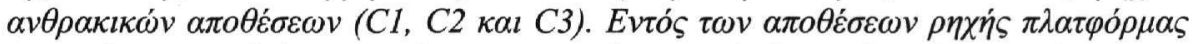

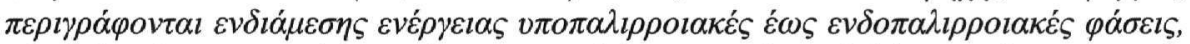

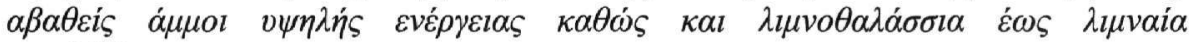
$\pi \varepsilon \rho \imath \beta \alpha \dot{\lambda} \lambda o v \tau \alpha$.

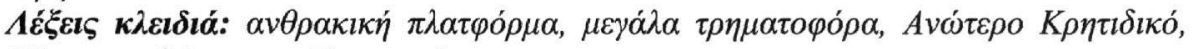

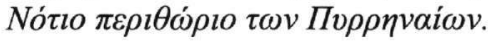

\section{Introduction}

Throughout most of the Cretaceous period, the area occupied nowadays by the Pyrenees was a deep and narrow furrow that extended between the Iberian and European plates. The palaeogeography of the Pyrenean gulf shows a basin with an east-west oriented axis (Pyrenean Basin), which extended from off-shore (Galicia, NW Spain) to the "Bassin de Beausset" (SE 
France), and opened into the Atlantic Ocean (Bay of Biscay). Shallow carbonate and siliciclastic carbonate platforms developed on both sides of the deep basin within the neritic domain.

As the result of the collision between the Iberian and European plates (Pyrenean-Alpine Orogeny), that occurred from the late Cretaceous to Oligocene period the materials deposited in these platforms were deformed, fragmented, detached from their substrate and displaced northwards and southwards, respectively along the Pyrenean axis. Nowadays, they form a puzzle of small units separated by tens or hundreds of kilometres, which are sometimes unrelated to their neighbours.

In this scenario, the control of biotic and abiotic events occurring in the shallow carbonate platform of each unit makes it possible to reconstruct the stratigraphic sequences, and calculate the temporal and spatial setting of each unit in the Pyrenean Basin during the Upper Cretaceous period. The work has been restricted to the central part of the south Pyrenean margin (Serres Marginals thrust-sheet).

\section{Geological setting}

The Serres Marginals thrust sheet, together with the Bòixols and Montsec thrust sheets, constitute the south verging thrust sheets of the Upper Thrust Sheets unit (Muñoz et al. 1984) from the southcentral Pyrenean unit (Seguret 1972) (Fig. 1). The main tectonic units are oriented almost in parallel to the Pyrenean basin axis, and document different palaeoenvironmental settings.

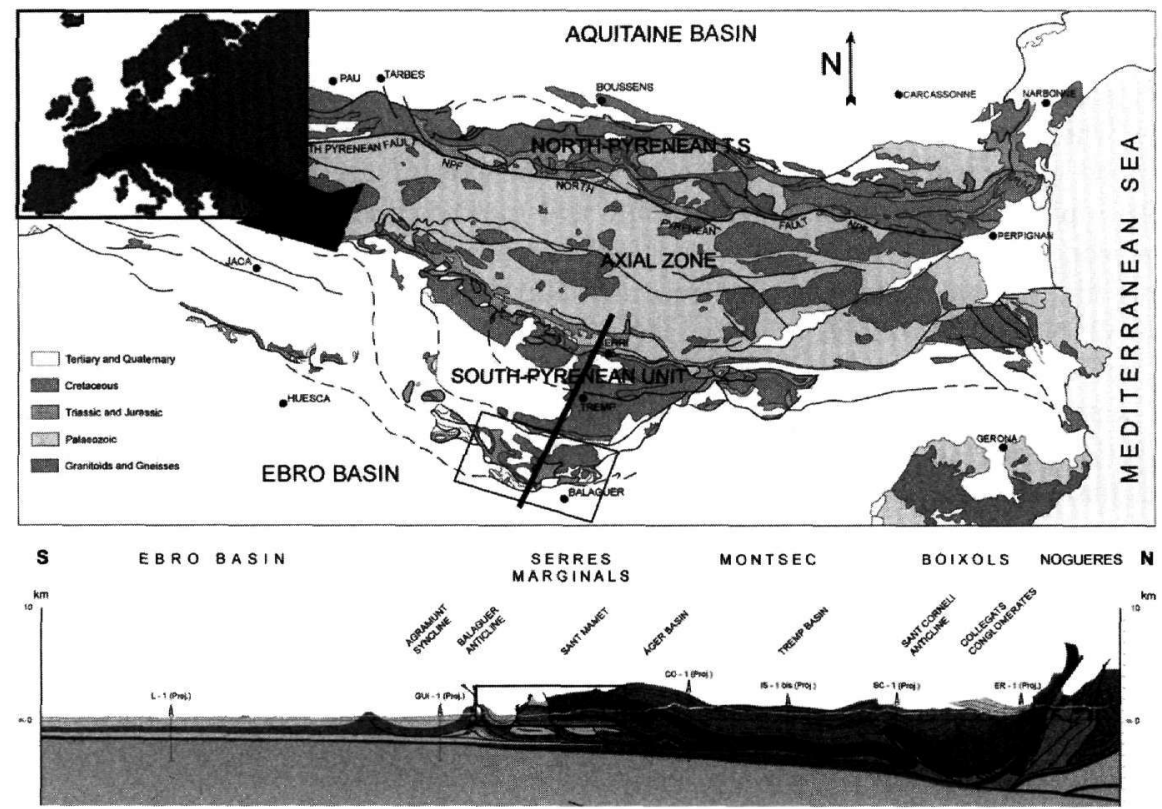

Figure 1 - General geological map of the Pyrenees. Black line indicates the ECORS profile, represented below. The squares indicate the Serres Marginals Unit, the studied area. (from Berástegui et al. 1993)

In the Pyrenees, the late Cretaceous deposits belong to two main tectonostratigraphic cycles (Berástegui et al. 2002). The lower cycle (late Cenomanian-early Santonian) corresponds to a transition phase, in which the Upper Cretaceous deposits reflect homogeneous and moderate subsidence, related to lithostratigraphical thermal contraction, after the initial extensional episodes that occurred during the Lower Cretaceous. During the upper cycle (late Santonian-Maastrichtian), the northern edge of the Iberian plate became a convergent margin, and the south margin of the Pyrenean basin registered a major change: the generation of a rapidly subsiding, terrigenous basin at the north of the studied area coeval with the growth of hanging-wall anticlines related to the 
emplacement of early thrust sheets (Bòixols thrust sheet, Fig. 1). In the shallower areas of the basin (Montsec and Serres Marginals thrust sheets, Fig. 1), the sedimentary response started with a coastal onlap of platform carbonates, which developed into a shallow carbonate platform system that extended landwards beyond the former basin margins. A shift from the early convergence to more widespread compression provoked a shallowing-upwards, regressive tendency in the study area, which is reflected by marsh lignitiferous black marls and continental red beds ("Garumnian facies": late Campanian to middle Palaeocene), the base of which has deposits very rich in dinosaur bones and nests.

\section{Material and methods}

An interdisciplinary study where mapping, and detailed stratigraphical and sedimentological analysis were integrated with paleontological data derived mainly from larger foraminifera was made. Several regionally spaced sections, covering all palaeoenvironmental settings within the Serres Marginals thrust sheet have been measured. The section exemplified in Fig. 2, made in the Coscoll cliff (Fig. 3) is one of the best exposed and most representative.

The use of larger foraminifera instead of other groups of fossils or microfossils is for the following reasons: 1. Larger foraminifera are abundant and diverse in the studied platform sediments. They are represented by large discoidal and conical agglutinated foraminifera, porcellaneous foraminifera such as fabulariids and meandropsinids, and lamellar-perforated siderolitids, rotaliids and orbitoidids. 2. Larger foraminifera are huge unicellular organisms, whose shells, which were obtained by growth-steps, reflect the complex morphology and structures through ontogeny. Therefore, an accurate analysis of such microfossils makes it possible to separate time dependent characters, which can be used in biostratigraphy, from characters with an environmental meaning, which can be used to interpret the paleoenvironment (Hottinger 1978). 3. Larger foraminifera occupy all tropical to subtropical oligothrophic and mesotrophic neritic paleoenvironments from the littoral zone to the lower limit of the photic zone (limit of the larger foraminifera bearing symbionts), and the palaeogeographical reconstruction of the Western Tethys placed the studied area in the $32^{\circ} \mathrm{N}$ (Dercourt et al. 1985). 4. Most of the genera and/or species of larger foraminifera replaced each other over a short period of time. 5 . The larger foraminifera are the only larger group of sallow-water fossils whose shells have sufficient diagnostic to be identified in thin sections to a taxonomic level of high-resolution biostratigraphic significance, and many shallow-water limestones that cannot be disaggregated by means of common methods.

\section{Facies, Palaeoenvironment and Age}

Lithologically, in the studied sections within the Serres Marginals thrust sheet, from bottom to top, the following units are distinguished: Les Serres Marginals sandy beds, Les Serres Marginals limestones and the "Garumnian" beds (Fig. 2).

\subsection{Les Serres Marginals sandy beds}

This unit overlies Jurassic sediments and is of a thickness varying from 55 to $76 \mathrm{~m}$. It consists of yellow sandy limestones, sands, clays and sandstones interbedded with marly limestones, marls and calcarenites, which can be partially dolomitized. The faunal content is represented by some irregularly distributed rudists (radiolitids) and oyster banks, fragmented echinoids and a rich fauna of larger foraminifera (Cuneolina cylindrica Henson, Pseudocyclammina sphaeroidea Gendrot, Dicyclina schlumbergeri Munier-Chalmas, Dictyopsella kiliani Munnier-Chalmas in Schlumberger, Accordiella conica Farinacci, Nezzazatinella picardi Henson, Meandropsina vidali Schlumberger, Nummofallotia cretacea Schlumberger, Lacazina elongata Schlumberger, Fascispira sp., Orbitokathina vonderschmitti Hottinger). Caus and Gómez-Garrido (1989) suggested a Late Santonian age for this unit. It is interpreted to have been deposited in a shallow platform area with major important terrigenous input. 


\subsection{Les Serres Marginals limestones}

The thickness of the unit varies from 100 to $300 \mathrm{~m}$, and four types of facies have been recognised in every measured section.

\subsubsection{Open marine carbonate facies}

Light grey limestones and marly limestones (packstone-wackestone) organised on a decimetre to metre-scale. Marly interbeds of thickness of a few centimetres are commonly observed. The faunal content is composed of bryozoa, echinoids, larger and smaller foraminifera, some fragmented bivalves and red algae, and locally sponge spicules. Larger foraminifera are represented by three successive assemblages: Op-1) Cuneolina cylindrica Henson, Pseudocyclammina sphaeroidea Gendrot, Dictyopsella sp. (small and flat forms), Fascispira sp., Nummofallotia cretacea Schlumberger, Praestorsella roestae Visser, Pararotalia tuberculifera (Reuss), Rotorbinella sp., and Praesiderolites douvillei Wannier. Op-2) Dictyopsella sp. (small and flat form), Fascispira sp., Nummofallotia cretacea Schlumberger, Praestorsella roestae Visser, Pararotalia sp., Praesiderolites dordoniensis Wannier, Orbitoides? concavatus Rahaghi, Lepidorbitoides cf. minima Douvillé. Op-3) Dictyopsella sp. (small and flat form), Fascispira sp., Praestorsella roestae Visser, Pararotalia sp., Praesiderolites sp., Pseudosiderolites aff. vidali Douvillé, Orbitoides? cf. concavatus Rahaghi, Neumannites granulosus Rahaghi, Vanderbeeckia sp., Lepidorbitoides cf. bisambergensis Jaeger. These facies are interpreted as deposited in a subtidal to intertidal environment near fare weather wave base, with a moderate energy.

\subsubsection{Sand-shoal, high energy facies}

Grey and brown thick-bedded to massive bioclastic limestones that are highly rich in bryozoa, echinoids, rudists, red algae and larger foraminifera. Some fragmented corals are also present. Larger foraminifera are represented by three assemblages: Sh-1) Abrardia catalaunica Bilotte, Orbitoides tissoti Schlumberger, Pseudosiderolites vidali Douvillé (small forms). Sh-2) Abrardia catalaunica Bilotte, Adrahentina iberica Bilotte, Biloculina fragilis Hofker, Orbitoides media d'Archiac and $O$. megaloformis Papp and Küper (replaced each other in time), Pseudosiderolites vidali Douvillé, Siderolites aff. calcitrapoides Lamarck (primitive form), Siderolites denticulatus Douvillé (primitive form). Sh-3) Orbitoides cf. gruembachensis Papp, Orbitoides? concavatus Rahaghi, Siderolites calcitrapoides Lamarck, Siderolites denticulatus Douvillé, Omphalocyclus macroporus (Lamarck) (rare). The limestones correspond to grainstones and packstones, and they present large-scale cross-bedding. This kind of facies is the most wideespread in the studied area, and the biological and lithological features of the sediments indicate a deposition under moderate to high energy shallow water with an important reworking the bioclasts.

\subsubsection{Protected lagoon, low-energy facies}

These consist of well stratified grey to pale brown and commonly bioturbated marly limestones. Lithologically, they are formed by wackestones-packestones with abundant larger foraminifera, dasycladacean algae, rudists and some corals indicating a protected marine area. Larger foraminifera are represented by three successive assemblages: L-1) Ilerdorbis decussatus Hottinger and Caus, Calveziconus lecalvezae Caus and Cornella, Abrardia catalaunica Bilotte, Cyclopsinella aff. steinmanni Munnier-Chalmas, Cyclolina aff. cretacea D'Orbigny, Broeckinella sp., Dicyclina schlumbergeri Munnier-Chalmas, Orbitokathina sp., L-2) Abrardia catalaunica Bilotte, Dicyclina schlumbergeri Munnier-Chalmas, Accordiella conica Farinacci, Nezzazatinella sp., Daviesina? L-3) Nezzazatinella sp., conical agglutinated foraminifera with exoskeleton (beams), Fascispira colom Silvestri, Omphalocyclus macroporus (Lamarck), Laffiteina sp., Daviesina cf. fleuriasi Hofker. These facies are interpreted as deposited in a protected area (lagoon) behind the sand-shoal facies (4.2.2). 


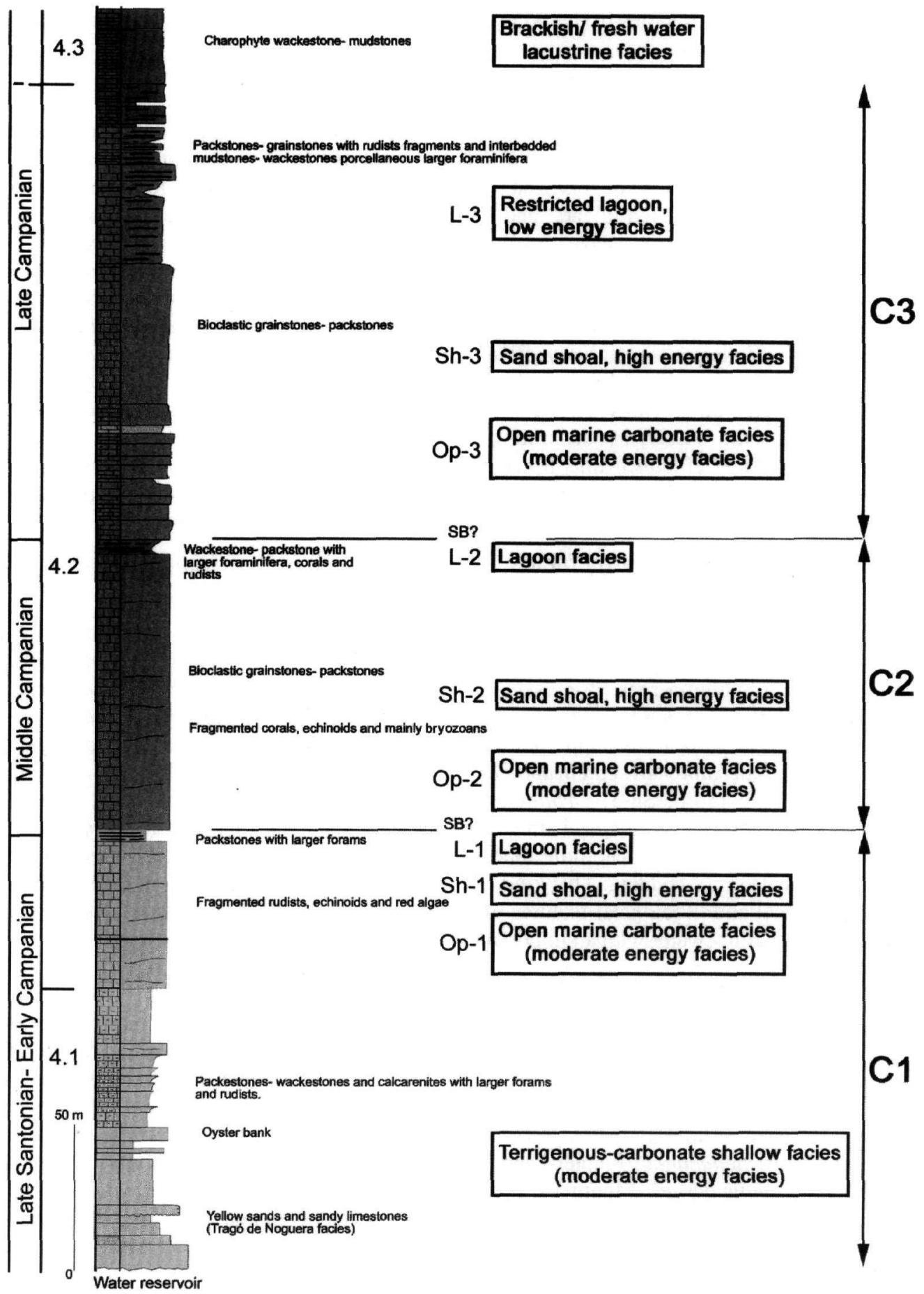

Figure 2 - The Coscoll section. See the distribution of facies and Larger Foraminiferal assemblages in the stratigraphic sequences $\mathrm{C} 1, \mathrm{C} 2$ and $\mathrm{C} 3$ 


\subsubsection{Restricted shallow-water, low energy facies}

Medium well bedded grey limestones and marly limestones (wackestones-packestones) with rudists and miliolids grading successively to "discorbid" and charophyte limestones. A continuous rudist biostrome is regularly distributed in all of the measured sections and can be used for correlation. The foraminiferal distribution indicates the passage from littoral marine to brackish lacustrine environment.

The temporal distribution of the larger foraminifera from each facies assemblages enables us to suggest that the Les Serres Marginals limestones date to the Early to Late Campanian.

\subsection{The "Garumnian" beds}

These consist of decimetric-thick grey micritic limestones with mainly charophyte remains, ostracods and fresh-water molluscs. Some packstones appear as formed by accumulations of charophytes, probably due to the storm reworking. They are interpreted as being brackish/fresh water lacustrine deposits.

\section{Stratigraphic sequences and events}

The spatial and temporal distribution of larger foraminifera together with the characteristics of the rocks enabled us to recognise three main stratigraphic sequences (see Fig. 2 and 3): the lowest one (carbonate platform 1) is composed of a terrigenous-carbonate shallow facies, moderately deep open marine carbonates, little developed sand-shoals and very well developed protected lagoonal facies. It belongs to the Late Santonian-Early Campanian. The middle sequence (carbonate platform 2) is characterised by well developed sand-shoal and protected lagoonal facies, and it is date . The upper one (Carbonate platform 3) includes well developed sand-shoal, protected lagoon, restricted shallow water and continental lacustrine deposits.

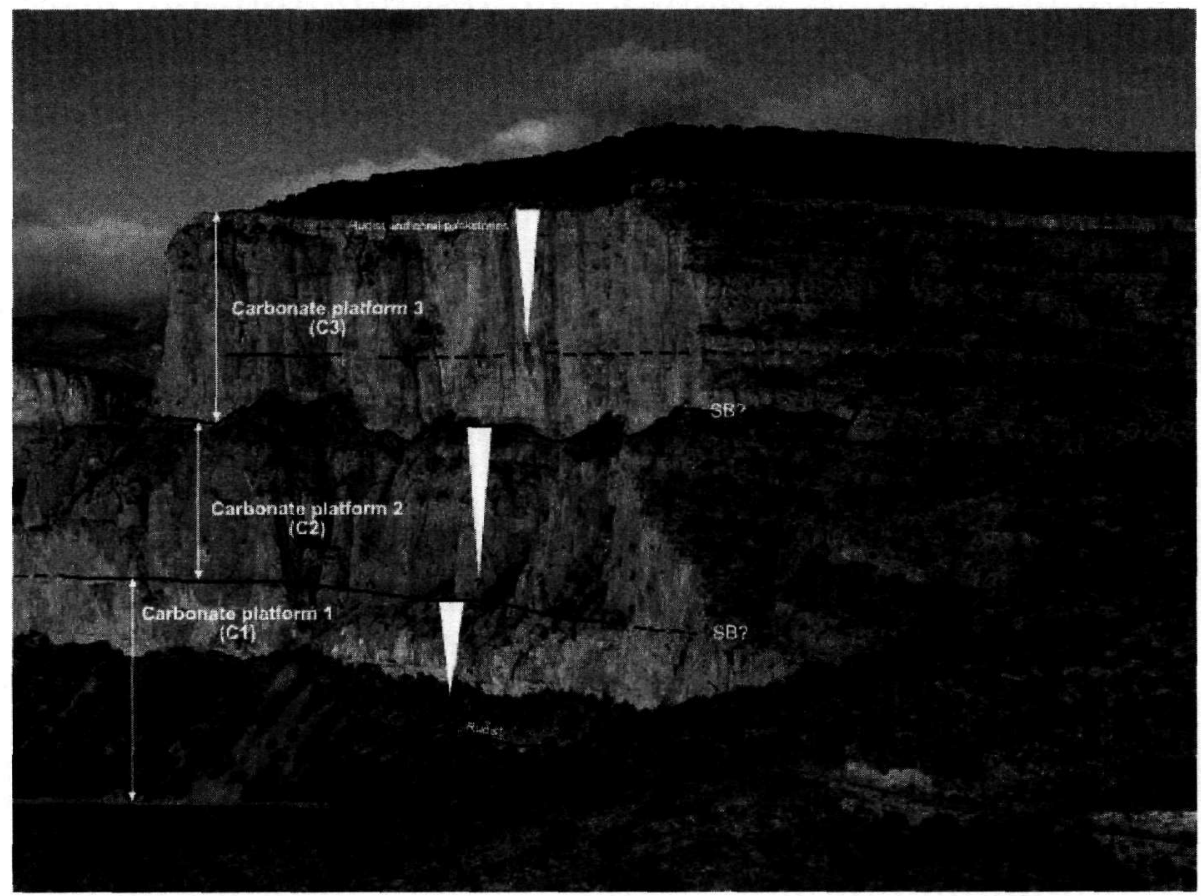

Figure 3 - Field view of the Coscoll section. Compare with Fig. 2

This homogeneous distribution of facies (and palaeoenvironments) in the whole of the studied area (central part of the south Pyrenean margin) suggests that the main agent responsible for the 
development of the three sequences is the relative change in the sea level, which increases or decreases the accommodation space. However, sequences one and three show evidence of tectonic activity. The terrigenous input at the base of the first sequence coincides with the beginning of the compressional phase in the Pyrenean (Alpine) Orogeny, whereas the generalised regression at the end of the third sequence is due to the intensification of the deformation. Therefore, the abiotic events controlling the growth and demise of the carbonate platforms were the eustatic cycles and tectonic activity mainly at the end of the third sequence.

The fossil distribution through the carbonate packages of the three sequences show the environmental and age constrains.

\section{Acknowledgments}

We are grateful to Joan Rosell (Universitat Autonoma de Barcelona) for help with the field-work. The study was financed by the Spanish Ministry of Education and Science, projects: BTE20000158 and BTE2003-04101.

\section{References}

Berástegui, X., Caus, E., and Puig, C., 2002. Pyrenees.In W. Gibbons and M.T. Moreno (eds), The Geology of Spain, Geological Society London, 265-272pp., London.

Berástegui, X, Losantos, M., Munoz, J.A., and Puigdefábregas, C., 1993. Geològic del Pirineu Central 1: 200.000, Institut Cartogràfic de Catalunya, Barcelona.

Dercourtm, J., Zonenshain, L.P., Ricoum, L. E, Kazminm, V.G, Le Pichonm, X, Knipper, A., Grandjacquet, C., Sorocktin, O., Geyssant, J., Lepvrier, C., Sborshchikov I.V., Boulin, J., Biju-Duval, B., Sibuet., J.C., Savostin, V., Westphal, M., and Lauer, J.P., 1985. Présentation de 9 cartes palóegeographiques au 1/20.000.000, s'étendant de l'Atlantique au Pamir pour la période du lias à l'actuel, Bulletin Societé Géolique de France 8/1, 5, 637-652.

Hottinger, L., 1978. Comparative Anatomy of Elementary Shell Structures in Selected Larger Foraminifera. In Hedley and Adams, Foraminifera, 3, 203-266.

Muñoz, J. A., Puigdefábregas, C., and Fontboté, J.M., 1984. Orógenos alpinos III. El Pirineo. In Geología de España. Instituto Geológico y Minero de España. 161-205.

Seguret, M., 1972. Etude téctonique des nappes et series décollés de la partie centrale du versant sud des Pyrenees. "Caractère synsedimentaire, ròle de la compression et de la gravité, $P h D$ Université de Montpellier, Ustela, sér. Geologie structurale, 2, 155pp. 